\title{
RAPESEED CROP DAMAGE BY WILDLIFE ASSESSED FROM LANDSAT IMAGES
}

\author{
ISTVÁN SISÁK \\ University of Szeged, Agricultural Faculty \\ Institute of Plant Sciences and Environmental Protection \\ 15. Andrássy St., H-6800 Hódmezővásárhely, Hungary \\ sisak.istvan@mgk.u-szeged.hu
}

\begin{abstract}
Rapeseed is the fourth most important crop in Hungary regarding its cultivation area. Crop damage by deer and boar has been becoming strongly debated issue in the last few years. More exact clarification of damage was aimed at in this study with help of Landast images. Six rapeseed fields were investigated both in 2012 and 2013 in the administrative area of Várfölde, Bánokszentgyörgy, Bázakerettye and Borsfa (Zala County, Hungary). The total area in 2013 was 43 hectares. $100 \%$ wildlife damage affected 3.9 hectares and 10 hectares were free from any damage. The total area in 2012 was 40 hectares in which 3.3 hectares were free from damage but neither fields suffered total damage. Yield map from 2017 of a 26 hectares field near to Gutorfölde and Szentkozmadombja was used to validate the space image based assessment method with real yield data. Landsat 7 images with acquisition dates of 2013.04.16., 2013.05.18. and 2013.06.03. were downloaded from the website of US Geological Service. All bands and NDVI index were investigated for all dates to establish best estimator for differences between damaged and not damaged fields. Band 5 (SWIR: $1.55-1.75 \mu \mathrm{m}$ ) in $16^{\text {th }}$ of April proved to be the best. It was concluded with help of the reflectance data (zero damage: 96.4 , complete damage: 164.5 , partial damage: 124.7 on the average) that yield reduction was $41.5 \%$ on areas with partial damage. There was no complete damage in 2012. However, reflectance data of not damaged fields were very close to each other in the two years (96.4 in 2013 and 89.9 in 2012 on the average) thus, it could be assumed that the same is true for reflectance data of completely damaged fields, so data from 2013 can be used for the comparison. Based on the data (zero damage: 89.9/2012, complete damage:164.5/2013, partial damage:118.4/2012 on the average) it was calculated, that one field suffered 38 $\%$ yield reduction, one hectare portion of another field suffered $23 \%$ yield reduction, and other fields were not damaged significantly. Yield map from 2017 and Landsat 8 SWIR reflectance (Band 6: 1.566 - 1.651 $\mu \mathrm{m})$ in $3^{\mathrm{rd}}$ of April have shown strong correlation $\left(\mathrm{R}^{2}=0,634\right)$, which was a direct evidence that both yield and wildlife damage of rapeseed can be reliably assessed from Landsat SWIR reflectance data acquired in April.
\end{abstract}

Keywords: rapeseed, damage by wildlife, Landsat 7, SWIR

\section{INTRODUCTION}

Rapeseed has been becoming more importance in the Hungarian agriculture for the last decades. Compared to the early 1990's when its production area was around 50 thousand hectares and the average yield varied between 1-2 tons per hectare, to-date it occupies more than 300 thousand hectares and the national average harvest has grown over 3 tons per hectare in the last few years with a record 3.6 tons per hectares in 2016 (KSH 2019a). The best farmers harvest well above 4 tons per hectare. Rapeseed advanced to the forth place among arable crops regarding the cultivation area (KSH 2019b) and being a high investment-high return commodity, it contributes significantly to the profitability of farms. Evidently any damage to this crop is a painful loss for the growers.

In the same period, large herbivore wildlife stocks soared too. Deer and boar combined bag increased from 81 thousand to 217 thousand between 1990 and 2018 (KSH 2019c). In the late 2000's and early 2010's the compensation for wildlife damage exceeded 2 billion Hungarian forint per year (CSÁNYI ET AL, 2011, 2012). Most of the damage was attributed to deer and boar (MÁTRAI AND JÁRÁSI 1986; BUZGÓ, 2006). Although systematic research on this relationship is scarce but there is a few spectacular anecdotal evidence for the 
damage (e.g. VAOL, 2019; VADKARINFO, 2019) and scientific analysis (BLEIER, 2014) has also confirmed the exponential relationship between deer and boar abundance and compensation. Most damage in Hungary affects maize but rapeseed damages by deer and boar are becoming more and more important especially in Zala county where wildlife abundance is high (BLEIER, 2014).

Our study aimed at investigating Landsat images as tools to more precisely determine rapeseed crop damage by wildlife.

\section{MATERIAL AND METHOD}

Six rapeseed fields were investigated both in 2012 and 2013 in the administrative area of Várfölde, Bánokszentgyörgy, Bázakerettye and Borsfa (Zala County, Hungary). The total area in 2013 was 43 hectares. $100 \%$ wildlife damage affected 3.9 hectares and 10 hectares (two fields) were free from any damage. That was confirmed by an official wildlife damage inspector in an official assessment. The total area in 2012 was 40 hectares in which 3.3 hectares were free from damage but neither fields suffered total damage. Again, this was confirmed in an official assessment. Yield map from 2017 of a 26 hectares field near to Gutorfölde and Szentkozmadombja was used to validate the space image based assessment method with real yield data. Data were recorded by a Green Star 3 Monitor. Study areas are shown on Figure 1. Landsat 7 images with acquisition dates of 2013.04.16., 2013.05.18. and 2013.06.03. were downloaded from the website of US Geological Service (USGS, 2019). All bands and NDVI indices were investigated for all dates to establish best estimator for differences between damaged and not damaged fields.

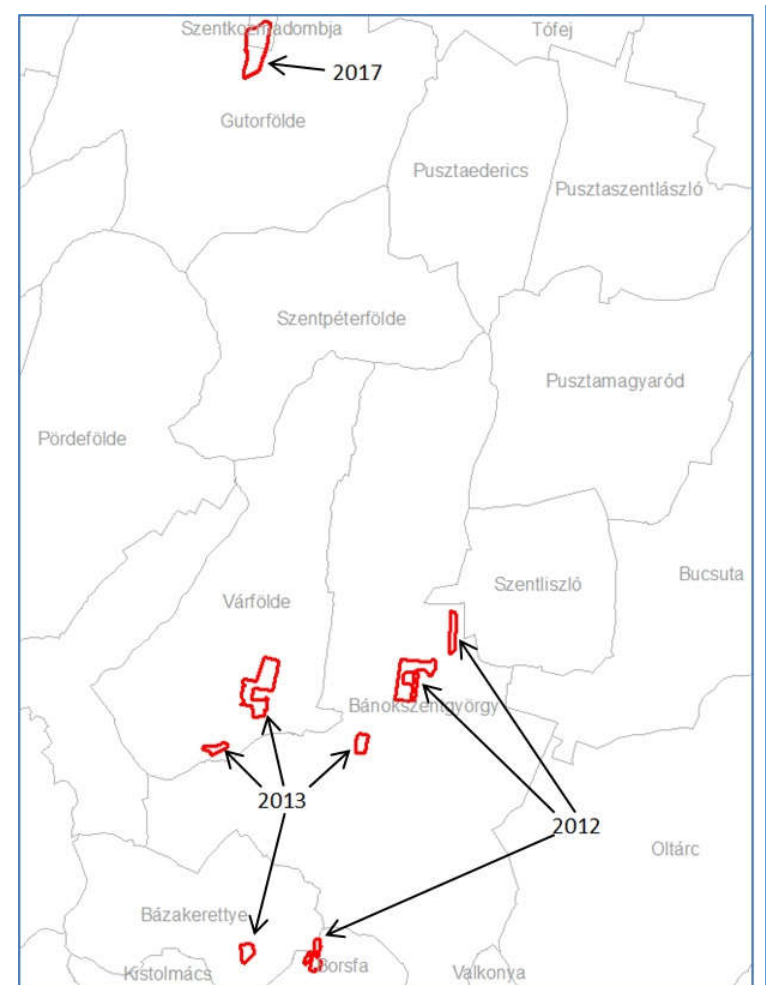

Figure 1. Study areas in Zala county

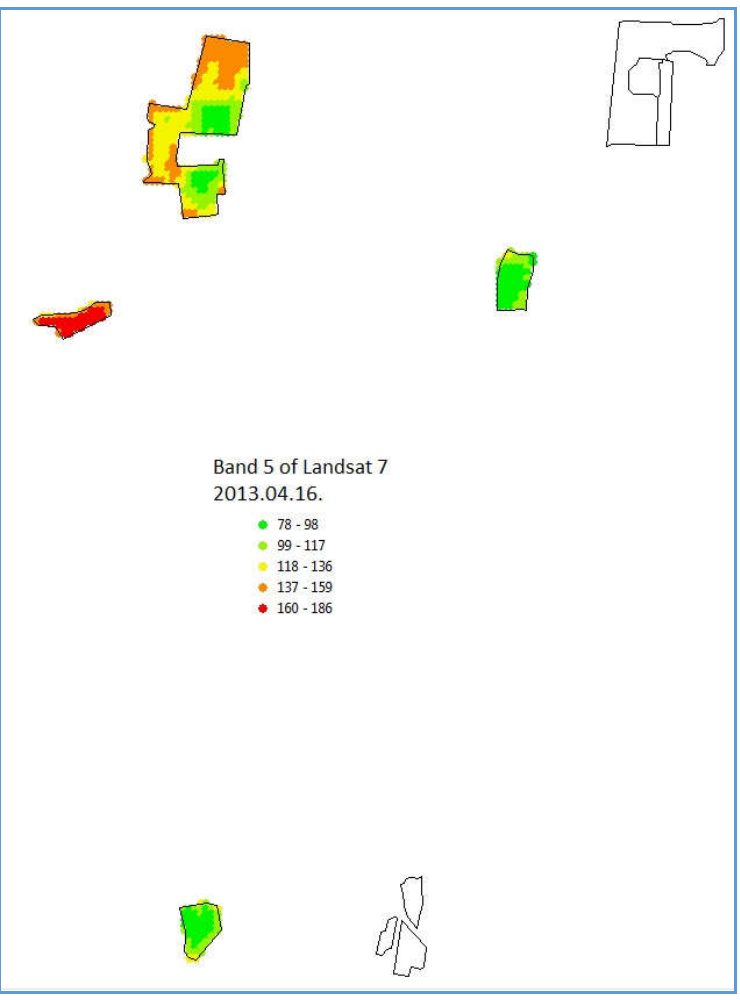

Figure 2. SWIR wavelength values in 2013

Landsat 7 images with acquisition date of 2012.04.29. and Landsat 8 images with acquisition date of 2017.04.03. were also downloaded from the same source and only the 
best estimator wavelength bands (selected in the previous step) were used to assess crop damage or to validate reflectance values with yield map data.

\section{RESULTS}

Landsat 7 band data from 2013 were grouped in three categories: total crop damage, partial crop damage and no crop damage by wildlife. NDVI indices were calculated for all the three dates from Band 4 and Band 3 data. One way analysis of variance was applied to distinguish between the categories. The differences were significant for all NDVI indices and all wavelengths (bands). F test value of the ANOVA were used to select the best predictors for differences (Table 1). Band 5 of April $16^{\text {th }}$ proved to be the best among all. Interestingly, NDVI indices performed rather poorly. This time the damaged crop was still in place. Band 5 and 7 of May $18^{\text {th }}$ were better but by that time the damaged field was disk tilled already so the sharper difference was consequence of the tillage not of wildlife damage.

Table 1. F test values for the different variables

\begin{tabular}{|c|c|c|c|c|c|}
\hline variable & F-value & remark & variable & F-value & remark \\
\hline May18_B7 & 402,72 & $*$ & April16_ndvi & 146,13 & \\
\hline May18_B5 & 325,37 & $*$ & May18_B4 & 115,99 & $*$ \\
\hline April16_B5 & 250,64 & best & June3_B3 & 95,34 & $*$ \\
\hline April16_B7 & 237,16 & & June3_ndvi & 94,39 & $*$ \\
\hline June3_B5 & 224,64 & $*$ & May18_B8 & 72,90 & $*$ \\
\hline May18_B3 & 216,29 & $*$ & June3_B4 & 70,13 & $*$ \\
\hline June3_B7 & 204,02 & $*$ & June3_B1 & 65,34 & $*$ \\
\hline May18_ndvi & 189,92 & $*$ & June3_B62 & 63,34 & $*$ \\
\hline April16_B3 & 185,89 & & June3_B61 & 61,82 & $*$ \\
\hline May18_B2 & 182,69 & $*$ & April16_B4 & 51,48 & \\
\hline May19_B1 & 179,26 & $*$ & May18_B62 & 51,08 & $*$ \\
\hline April16_B1 & 177,11 & & May18_B61 & 43,92 & $*$ \\
\hline April16_B2 & 174,24 & & June3_B8 & 27,86 & $*$ \\
\hline April16_B61 & 155,97 & & April16_B8 & 15,67 & \\
\hline April16_B62 & 154,68 & & June3_B2 & 4,23 & $*$ \\
\hline
\end{tabular}

*after disc cultivation on the field which were totally demaged by wildelife

Band 5 is the short wave infrared reflectance (SWIR: 1.55-1.75 $\mu \mathrm{m}$ ). Its spatial distribution is shown on Figure 2. Considering the endpoints of the scale (no damage $=96.4$ vs. total damage $=164.5$ ) as detailed on Figure 3, the partial damage can be calculated: $41.5 \%$. Considering the area (28.6 ha) and the yield on not damaged area ( $4 \mathrm{t} / \mathrm{ha})$ the total yield loss is 47 tons.

There was no complete damage in 2012. However, reflectance data of not damaged fields were very close to each other in the two years (96.4 in 2013 and 89.9 in 2012 on the average) thus, it could be assumed that the same is true for reflectance data of completely damaged fields, so data from 2013 can be used for the comparison. Based on the data (zero damage: $89.9 / 2012$, complete damage:164.5/2013, partial damage:118.4/2012 on the average) it was calculated, that one field suffered $38 \%$ yield reduction and a one hectare portion of another field suffered $23 \%$ yield reduction. Three other fields were not 
damaged significantly. Based on the areas and average yield $(4.3 \mathrm{t} / \mathrm{ha})$ the total yield loss was 15 tons.

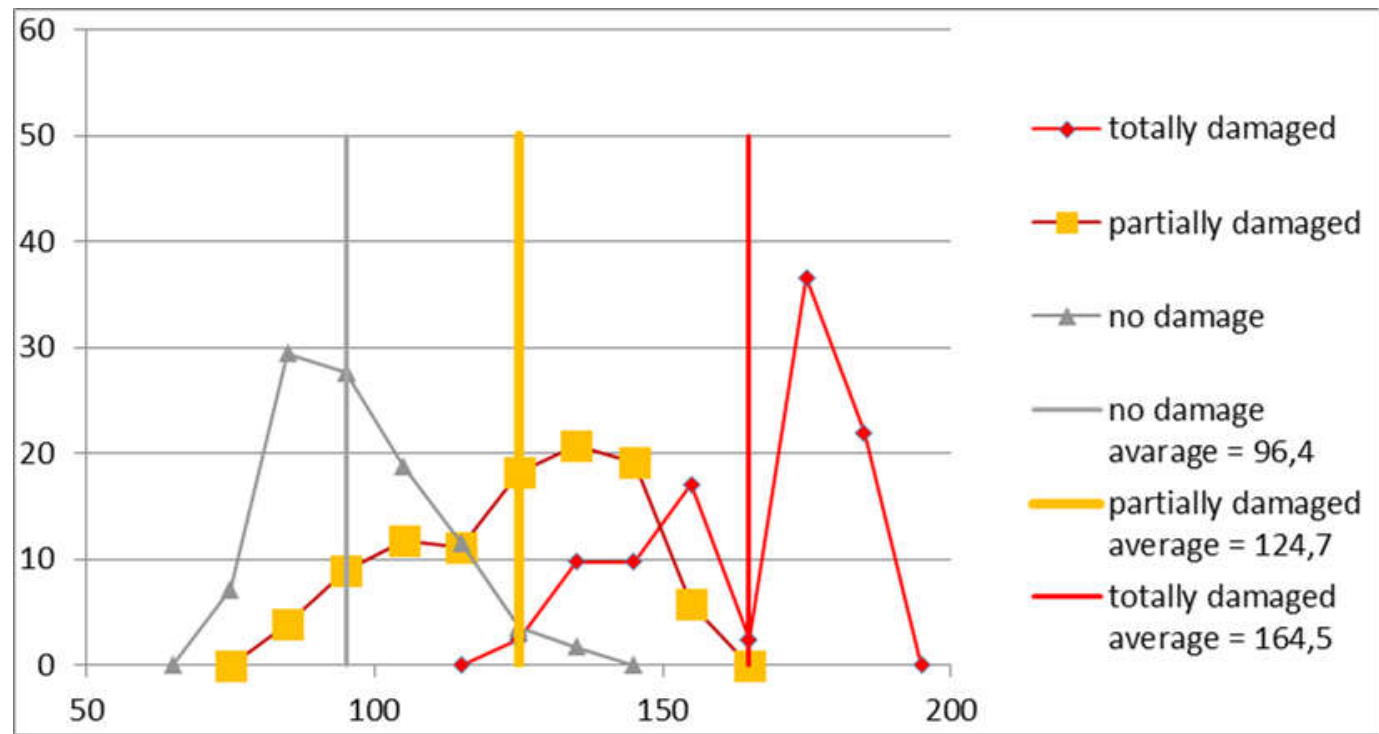

Figure 3. Distribution and averages of SWIR reflectance values for 2013

Landsat 8 SWIR reflectance (Band 6: $1.566-1.651 \mu \mathrm{m}$ ) in $3^{\text {rd }}$ of April 2017 were validated with yield map from 2017. Landsat 8 images have pixel values between $0-65535$ $\left(2^{16}\right)$ while Landasat 7 images between $0-255\left(2^{8}\right)$. Pixel values were recalculated to the range of Landsat 7 images, yield data were averaged for the 30x30 metre pixels of the images, and yield values with same reflectance value were averaged too. The relationship between pixel reflectance values and yield was acceptably strong $\left(\mathrm{R}^{2}=0.634\right.$ Figure 4$)$.

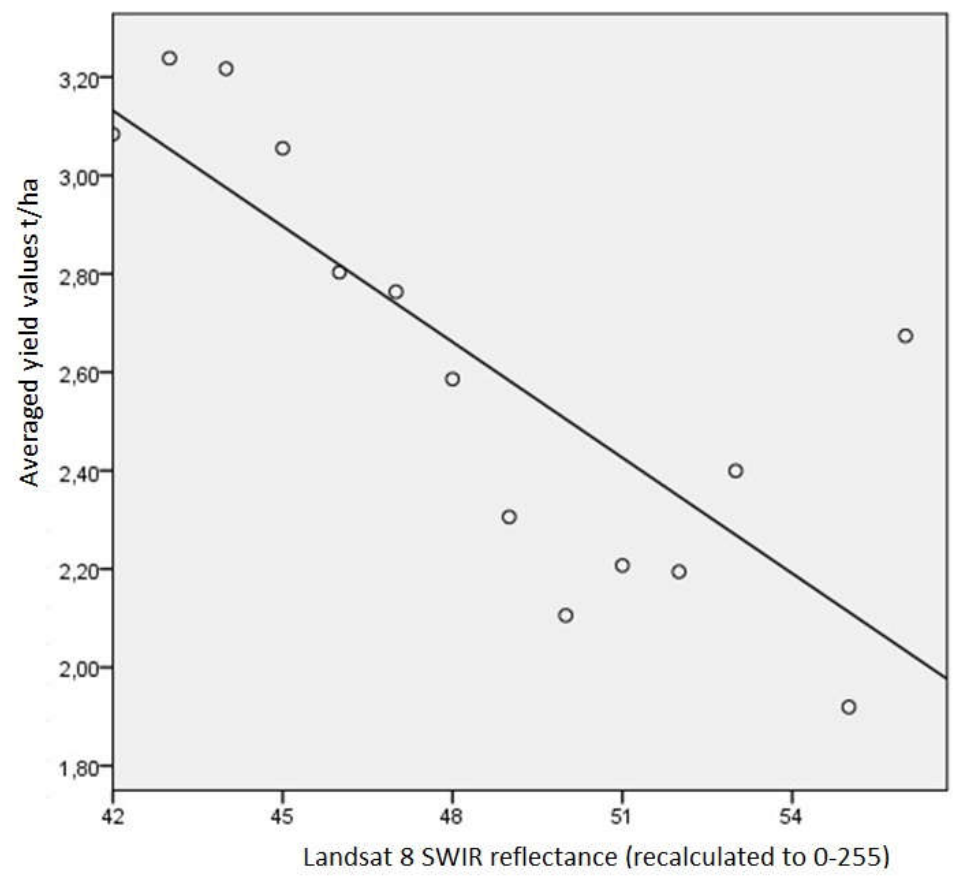

Figure 4. Regression between SWIR reflectance and averaged yield map data 


\section{CONCLUSIONS}

Remarkable conclusion from our study that NDVI indices performed worse than SWIR reflectance. April is the flowering time of rapeseed when very intensive biochemical processes are going on parallel with a rapid growing. The SWIR reflectance value in April correlated very well with the yield harvested in early July as evidenced by the investigation for 2017. The distributions of the pixel values for 2013 (Figure 3) show some skewness for the not damaged area indicating weaker spots even in a field with high average yield. The pixel values for partly damaged field have overlapping bimodal distribution indicating relatively undamaged spots within the field. The pixel values for completely damaged filed show two distinct distribution. Higher values might indicate bare ground with total destruction of the crop and lower values might represent still existing, highly damaged crop. The divide between the two groups is exactly at the point where the distribution of partial damage cases which also confirms that conclusion.

Finally the conclusion can be drawn that SWIR reflectance values in April are good indicators for rapeseed yield and the proposed method is an appropriate tool for wildlife damage assessment in case reference values for zero and total damage are available.

\section{REFERENCES}

BLEIER N. (2014): A mezőgazdasági vadkár ökológiai és ökonómiai összefüggései.

Doktori (PhD) értekezés, Szent István Egyetem, Gödöllő

BUZGÓ J. (2006): A szarvasfélék túlszaporodásából eredő problémák áttekintő vizsgálata és a megoldás lehetőségei. Doktori értekezés, Sopron

CSÁNYI S., LEHOCZKI R., SONKOLY K. (szerk.) (2011): Vadgazdálkodási Adattár, 2010/2011 vadászati év. Szent István Egyetem, Vadbiológiai és Vadgazdálkodási Tanszék, Gödöllö. 52pp. ISSN 14174308

CSÁNYI S., SONKOLY K., LEHOCZKI R. (szerk.) (2012): Vadgazdálkodási Adattár, 2011/2012 vadászati év. Szent István Egyetem, Vadbiológiai és Vadgazdálkodási Tanszék, Gödöllö. 52pp. ISSN 14174308

KSH 2019a https://www.ksh.hu/docs/hun/xstadat/xstadat_eves/i_omn007b.html

KSH $2019 \mathrm{~b}$ http://www.ksh.hu/docs/hun/xftp/gyor/vet/vet1806.pdf

KSH 2019c https://www.ksh.hu/docs/hun/xstadat/xstadat eves/i_ux001b.html MÁTRAI G., JÁRÁSI J. (1986): Az 1985. év vadgazdálkodása és a 1986. év feladatai.

Nimród Fórum, 106 (8): 1-7.

VADKARINFO (2019): http://vadkarinfo.hu/2019/03/09/itt-az-ideje-tavaszi-vadkarfelmereskepekben/

VAOL (2019): https://www.vaol.hu/kozelet/helyi-kozelet/hatalmas-rudli-dezsmalja-avetest-szombathely-hataraban-2767720/

USGS (2019): https://earthexplorer.usgs.gov/ 